\title{
Use of ultrasound to enhance PEl-mediated gene delivery in vivo on diabetic model
}

\author{
Rostyslav V Bubnov ${ }^{1 *}$, Olena K Toporova², Dmytro M Irodov², Tamara P Gulko², Tetiana P Ruban², \\ Pavlo V Morgunov², Vitaliy A Kordium² \\ From EPMA-World Congress 2013 \\ Brussels, Belgium. 20-21 September 2013
}

\section{Background and aims}

Gene therapy has strong therapeutic potential for the personalized treatment of type 1 diabetes. Local gene delivery methods for gene therapy are a promising strategy to increase the therapeutic genes concentration at the target location. Transient ultrasound can cause the local increase of cell membrane permeability thus promoting the penetration of transfection particles into the cell.

\section{The objective}

of this work is to evaluate transfection efficiency and safety for intrahepatic polyplex-mediated gene delivery by sonoporation.

\section{Methods}

Polyplexes of expression vector DNAs complexed to galactose-bearing polyethylenimine (L-PEI) have been used. Expression vectors are two plasmids containing expression cassette for full-size human preproinsulin gene controlled with CMV promoter and flanked by inverted terminal repeats of AAV (pTRhins) and the same cassette for marker gfp gene (pTRegfp). Animals were injected under US guidance with polyplexes in a dose of $40 \mu \mathrm{g}$ pTRegfp $/ 0.7 \mathrm{ml}$ (rat) and of $15 \mu \mathrm{g}$ pTRhins $/ 0.15 \mathrm{ml}$ (diabetic mouse) into the liver parenchyma of subdiaphragmal segments using $31 \mathrm{G}$ needles. Afterwards injection locus in depth of $1 \mathrm{~cm}$ during $180 \mathrm{sec}$ was insonated by $130 \mathrm{Db}$ ultrasound using multifrequency 3-5 $\mathrm{MHz}$ probe.

\section{Results}

Sonoporation is able to increase polyplex gene transfer to liver cells in vivo. Flow cytometry analysis of primary

\footnotetext{
* Correspondence: rostbubnov@gmail.com

"Clinical hospital "Pheophania" of State Affairs Department, Kyiv, Ukraine
} Full list of author information is available at the end of the article hepatocytes isolated from the liver of experimental rats showed that ultrasound -enhanced polyplex gene transfer was highly localized, and was superior to all controls. At least $42 \%$ of the liver cells in vivo can be transfected in this way with ultrasound exposure versus $1.2 \%$ without it. Hypoglycemic effect of the insulin gene delivery followed by 3 min US exposure was observed on the third day: glucose level of diabetic mice (hyperglycemic 6 - week) decreased in average by $30 \%$. Nevertheless sonoporation does not increase naked plasmid DNA (without L-PEI ) transfection efficiency. A week and a month after the procedure serial sections from rat liver injected with polyplexes containing $40 \mu \mathrm{g}$ marker plasmid or saline solution alone exposed to US and without it was analyzed for the presence of inflammation. Pathomorphological and histological analysis of experimental livers revealed no inflammatory processes in tissues, and any detectable side effects of US-enhanced gene delivery were seen. Experimental mice and rat liver DNAs were positive in transgene PCR for 3 months after gene delivery.

\section{Conclusions}

Our results demonstrate that polyplex gene transfer by US exposure is effective, robust and feasible and illustrate the potential of ultrasound-triggered gene delivery technology for gene therapy.

\section{Outlook and expert recommendations}

As a follow-up to this study, it is recommended to create project to study and implement diabetic gene therapy with drug delivery systems for personalized treatment of type 1 diabetes.

\section{Authors' details}

${ }^{1}$ Clinical hospital "Pheophania" of State Affairs Department, Kyiv, Ukraine. ${ }^{2}$ Institute of Molecular Biology and Genetics of NAS of Ukraine, Kyiv, Ukraine. 


\section{Reference}

1. Toporova OK, Irodov DM, Bubnov RV, Kholodkova OL, Gulko TP, Ruban TP, Morgunov PV, Kordium VA: Intrahepatic ultrasound-mediated gene delivery. J Hepatol 2013, 58(Suppl 1):119, doi:10./S0168-8278(13)60283-4.

doi:10.1186/1878-5085-5-S1-A76

Cite this article as: Bubnov et al:: Use of ultrasound to enhance PEI-

mediated gene delivery in vivo on diabetic model. EPMA Journal 20145 (Suppl 1):A76.

Submit your next manuscript to BioMed Central and take full advantage of:

- Convenient online submission

- Thorough peer review

- No space constraints or color figure charges

- Immediate publication on acceptance

- Inclusion in PubMed, CAS, Scopus and Google Scholar

- Research which is freely available for redistribution 